\title{
Postharvest Ascorbate Metabolism in Two Cultivars of Spinach Differing in Their Senescence Rates
}

\author{
D. Mark Hodges ${ }^{1}$ and Charles F. Forney \\ Atlantic Food and Horticulture Research Centre, Agriculture and Agri-Food Canada, 32 Main Street, \\ Kentville, Nova Scotia, B4N 1J5 Canada
}

\begin{abstract}
AdDitIonal INDEX WORDs. lipid peroxidation, oxidative stress, postharvest, storage quality, vitamin C
ABSTRACT. Rapidly declining levels of ascorbate (vitamin C) have been associated with advancing senescence and postharvest quality loss in spinach (Spinacia oleracea $\mathrm{L}$.). To further explore the association between ascorbate metabolism and senescence, two cultivars of spinach previously shown to differ in their postharvest senescence rates were grown under controlled conditions $\left(18^{\circ} \mathrm{C}, 14\right.$ light : 10 dark photocycle) and harvested 6 weeks after planting. Detached leaves of 'Spokane F1' (relatively fast senescence rate) and 'BJ412 Sponsor' (relatively slow senescence rate) were bagged and placed in the dark at $10^{\circ} \mathrm{C}$. Samples were removed on days $0,7,14,21$, and 28 , and analyzed for activities of $L$-galactono- $\gamma$-lactone dehydrogenase (GLDH), ascorbate peroxidase (ASPX), ascorbate oxidase (AAO), dehydroascorbate reductase (DHAR), and monodehydroascorbate reductase (MDHAR), and levels of ascorbate [reduced (AsA) and oxidized (DHA)] and malondialdehyde (MDA) (estimator of lipid peroxidation). Oxidative stress, as estimated by MDA levels, steadily increased in both spinach cultivars during storage, but increased more in 'Spokane' than in 'Sponsor'. GLDH activities peaked on day 14 for both cultivars and leveled off thereafter, while activities of ASPX, DHAR, and MDHAR declined during storage. ASPX activities were lower in 'Spokane' than in 'Sponsor' after day 21. No difference in AAO activities was noted between 'Sponsor' and 'Spokane' during storage. Total ascorbate concentrations declined in both cultivars on day 14 after which no further decreases were noted, while DHA/AsA ratios increased during storage. Early in the storage regime (days 0 and 7), ascorbate levels were lower in 'Spokane' than in 'Sponsor. GLDH activities may have increased as part of a strategy to maintain the ascorbate pool during escalating oxidative stress. However, decreased levels of ascorbate suggests that, even though ascorbate biosynthesis was increased, ascorbate was being degraded, possibly through hydrolysis of DHA to 2,3-diketogulonate. Initially lower levels of ascorbate (days 0 and 7) and lower activities of ASPX (day 28) in 'Spokane' may have resulted in comparatively greater susceptibility of this cultivar to oxidative stress than 'Sponsor'.
\end{abstract}

It has been well documented that total ascorbate levels frequently decline in harvested fruits and vegetables during storage (Hodges and Forney, 2000; Hodges et al., 2001; Yamauchi and Kusabe, 2001; Zee et al., 1991). Such losses can be due to a number of factors, such as oxidation, $\mathrm{pH}$, relative humidity, and temperature (Yahia et al., 2001). Ascorbate performs various functions within plant systems, including roles as an antioxidant and as an enzyme co-factor, participation in photosynthetic and mitochondrial electron transport chains, and involvement in cell wall metabolism and cell expansion (Smirnoff, 2000). Currently, it is proposed that the ascorbate biosynthetic pathway begins with GDP-mannose and ends with the conversion of L-galactono- $\gamma$ lactone to ascorbate through the catalytic action of L-galactono$\gamma$-lactone dehydrogenase (GLDH; EC 1.3.2.3).

Although ascorbate is involved in such processes as the de-epoxidation of violaxanthin (Ederli et al., 1997) and the regeneration of $\alpha$-tocopherol (Horemans et al., 2000), and can react directly with the active oxygen species superoxide $\left(\mathrm{O}_{2}^{-}\right)$, singlet oxygen $\left({ }^{1} \mathrm{O}_{2}\right)$, and the hydroxyl radical $(\bullet \mathrm{OH})$, one of the most studied antioxidant functions of this compound is its role in the reduction of $\mathrm{H}_{2} \mathrm{O}_{2}$ to $\mathrm{H}_{2} \mathrm{O}$, a reaction catalyzed by the enzyme ascorbate peroxidase (ASPX; EC 1.11.1.11). Ascorbate becomes oxidized to the intermediate monodehydroascorbate radical, which can be converted back to ascorbate by one of three avenues: a) reduction by monodehydroascorbate reductase (MDHAR; EC 1.6.5.4), b) action as a direct electron acceptor to Photosystem I at the ferre-

Received for publication 7 Apr. 2003. Accepted for publication 16 July 2003. Atlantic Food and Horticulture Research Centre contribution 2255. The authors wish to thank John DeLong and Jun Song, Atlantic Food and Horticulture Research Centre, Kentville, Nova Scotia, for critical review of this manuscript, and Ken McRae, Brad Walker, and Eric O'Neill for assistance with statistical analysis. ${ }^{1}$ Corresponding author; e-mail HodgesM@agr.gc.ca. doxin site, or c) disproportionation of two monodehydroascorbate molecules to ascorbate and dehydroascorbate (DHA) (De Gara et al., 2000; Smirnoff, 2000). DHA can then be reduced to ascorbate through the action of dehydroascorbate reductase (DHAR; EC 1.8.5.1). Ascorbate can also become oxidized to DNA by the action of the $\mathrm{Cu}$-containing enzyme ascorbate oxidase (AAO; EC 1.10.3.3). Although AAO is thought to be an important enzyme in ascorbate oxidation, its metabolic function has not yet been fully elucidated (Yahia et al., 2001), although evidence suggests that it may be involved in plant cell growth (Kato and Esaka, 2000). Ascorbate oxidation can continue beyond DHA. DHA is highly unstable above $\mathrm{pH} 7$ and, unless reduced to ascorbate, will irreversibly hydrolyze to 2,3-diketogulonate and further be degraded to over 50 different products (Deutsch, 1998). Metabolic products of ascorbate include oxalate and tartrate (Saito, 1996).

Leaf senescence may involve degradation of proteins, chlorophyll (Hodges and Forney, 2000), nucleic acids (Buchanan-Wollaston, 1997), and/or membranes (Trippi and Thimann, 1983). Physical detachment of leaves has been demonstrated to promote or accelerate symptoms of early leaf senescence (Bartoli et al., 1996; Philosoph-Hadas et al., 1991). Relationships between leaf oxidative and antioxidative potentials have been implicated in senescence dynamics (Hodges, 2003; Kanazawa et al., 2000; Kunert and Ederer, 1985).

Past work has suggested that ascorbate plays a direct role in delaying senescence, possibly through the inhibition of $\mathrm{H}_{2} \mathrm{O}_{2}$ accumulation (Borraccino et al., 1994; Hodges and Forney, 2000; Hodges et al., 2001; Jiménez et al., 1998; Piquery et al., 2000). In a preliminary examination of a variety of enzymic and nonenzymic antioxidants in detached leaves of two cultivars of spinach (Spinacia oleracea) differing in their postharvest senescence rates, we had demonstrated that the spinach cultivar which 
showed the higher rate of senescence also exhibited significant declines in ASPX activities and a more rapid loss of total ascorbate (Hodges et al., 2001). The purpose of the current study was to further investigate the biosynthesis and metabolism of ascorbate in detached leaves of these two spinach cultivars which differ in their postharvest senescence rates.

\section{Materials and Methods}

Plant Material. Seeds of the spinach cultivars 'BJ412 Sponsor' and 'Spokane F1' (Warmenhuizen, Holland, The Netherlands) were sown individually in $15-\mathrm{cm}$ pots and placed in controlled environment chambers (Econaire GR36, Winnipeg, Manitoba, Canada) at $18{ }^{\circ} \mathrm{C}$ and $95 \%$ relative humidity with a photocycle of 10 light : 14 dark $\left(450 \mu \mathrm{mol} \cdot \mathrm{m}^{-2} \cdot \mathrm{s}^{-1}\right)$. After 6 weeks of growth, all leaves except the four oldest were harvested, mixed, sampled, and placed in perforated bags (100 $\mathrm{g}$ fresh weight/bag). Bags were then sealed and put in a chamber (Econaire GR100) maintained without light at $10^{\circ} \mathrm{C}$ and $95 \%$ relative humidity. Three bags per cultivar were removed on days $0,7,14,21$, and 28 . This experiment was repeated twice.

LIPID PEROXIDATION. Lipid peroxidation was estimated spectrophotometrically (Ultraspec 3000, Pharmacia Biotech) in 7.5 to $10 \mathrm{~g}$ fresh weight samples of spinach tissue using the TBARSMDA test as described by Hodges et al. (1999), which corrects for compounds other than the TBA-MDA adduct which absorb at $532 \mathrm{~nm}$.

Ascorbate BIOSYNTHESIS. Activities of GLDH were analyzed in mitochondrial enriched fractions by following cytochrome $c$ reduction (De Gara et al., 1997; 2000). Enzyme extracts were prepared by homogenizing $10 \mathrm{~g}$ fresh weight spinach tissue in a prechilled mortar and pestle nestled in ice along with $0.5 \mathrm{~g}$ inert sand, $0.5 \mathrm{~g}$ PVP, and $50 \mathrm{~mL}$ ice-cold extraction buffer $(30 \mathrm{~mm}$ MOPS, $25 \mathrm{~mm} \mathrm{Na}_{4} \mathrm{P}_{2} \mathrm{O}_{7}, 2$ mm EDTA, 0.2\% BSA, 4 mm cysteine, and $0.35 \mathrm{~m}$ mannitol at $\mathrm{pH} 7.5)$. Extracts were filtered through four layers of cheesecloth and then centrifuged (Sorvall RC-5C plus, Dupont Instruments) at $1500 g_{n}$ for $10 \mathrm{~min}$ at $4{ }^{\circ} \mathrm{C}$. The supernatant was decanted and centrifuged again at $14,000 g_{n}$ for $15 \mathrm{~min}$ at $4{ }^{\circ} \mathrm{C}$. The resulting pellet was gently resuspended with a glass rod in $30 \mathrm{~mL}$ of ice-cold wash media (20 mm MOPS, $1 \mathrm{~mm}$ EDTA, and $0.3 \mathrm{M}$ mannitol at $\mathrm{pH} 7.2$ ), followed by centrifugation at $14,000 g_{\mathrm{n}}$ for $15 \mathrm{~min}$ at $4{ }^{\circ} \mathrm{C}$. The pellet was resuspended in $0.5 \mathrm{~mL}$ wash media.

The 1-mL assay mixture for GLDH activity determinations contained 60 mm Tris- $\mathrm{HCl}(\mathrm{pH} 8.0), 1.5 \%$ (w/v) Triton X-100, $2 \mathrm{~mm}$ galactono- $\gamma$-lactone, and $30 \mu \mathrm{L}$ extract. The reaction was initiated with the addition of $0.18 \mathrm{~mm}$ cytochrome $\mathrm{c}$, and the absorbance change at $550 \mathrm{~nm}$ was followed at $25^{\circ} \mathrm{C}$ every $30 \mathrm{~s}$ for $3 \mathrm{~min}$ on a spectrophotometer (Ultraspec 3000, Pharmacia Biotech) equipped with a water bath (Endocal RTE-5B; Neslab, Portsmouth, N.H.) for calibrated temperature control.

Ascorbate metabolism. For ASPX, DHAR and MDHAR analyses, enzyme extracts were prepared by homogenizing spinach leaves ( 7.5 to $10 \mathrm{~g}$ fresh weight) in a prechilled mortar and pestle nestled in ice along with $0.5 \mathrm{~g}$ inert sand, $0.25 \mathrm{~g}$ PVP, and $30 \mathrm{~mL}$ chilled extraction buffer $(100 \mathrm{~mm}$ Tris- $\mathrm{HCl}, 1.0 \mathrm{~mm}$ EDTA, $0.05 \%$ [w/v] cysteine, and $1.0 \mathrm{~mm} \mathrm{L-ascorbic} \mathrm{acid} \mathrm{at} \mathrm{pH}$ 7.8). Extracts were then centrifuged at $10,000 g_{n}$ for $15 \mathrm{~min}$ at $4{ }^{\circ} \mathrm{C}$ and the supernatants analyzed. For DHAR assays, the supernatants were immediately depleted of low-molecular-weight compounds by passage through a mini-column (Sephadex G25 PD-10; Pharmacia Biotech, Uppsala, Sweden) preequilibrated with the extraction buffer. Enzyme assays were conducted immediately following extraction.

ASPX activity was determined using a method described by Nakano and Asada (1987). The 1-mL assay mixture contained $90 \mathrm{~mm}$ potassium phosphate buffer ( $\mathrm{pH} 7.0), 0.1 \mathrm{~mm}$ EDTA, 0.65 mu L-ascorbic acid, and $15 \mu \mathrm{L}$ extract. The reaction was initiated with the addition of $1.0 \mathrm{mM} \mathrm{H}_{2} \mathrm{O}_{2}$. Activity was determined at 25 ${ }^{\circ} \mathrm{C}$ by following the oxidation of ascorbate at $290 \mathrm{~nm}$ every $30 \mathrm{~s}$ for $1.5 \mathrm{~min}$.

DHAR activity was assessed following Doulis et al. (1997). The 1.5-mL assay mixture contained $90 \mathrm{~mm}$ potassium phosphate buffer (pH 7.0), 1 mм EDTA, 5.0 mм reduced glutathione (GSH), and $10 \mu \mathrm{L}$ extract. The reaction was initiated with the addition of $0.2 \mathrm{~mm}$ DHA and activity was determined at $25^{\circ} \mathrm{C}$ by following the reduction of DHA at $265 \mathrm{~nm}$ every min for $3 \mathrm{~min}$ after accounting for the nonenzymic reduction of DHA by GSH.

MDHAR activity was assayed following Hossain et al. (1984). The 1-mL assay mixture contained $90 \mathrm{~mm}$ potassium phosphate buffer (pH 7.5), 0.0125\% Triton-X-100, 0.2 mм NADH, $2.5 \mathrm{~mm}$ $\mathrm{L}$-ascorbic acid, and $30 \mu \mathrm{L}$ extract. The reaction was initiated with the addition of 0.25 units of ascorbate oxidase (units as defined by Sigma Chem. Co.). The reaction was followed at $25^{\circ} \mathrm{C}$ every 30 $\mathrm{s}$ for $3 \mathrm{~min}$ by measuring the decrease in absorbance at $340 \mathrm{~nm}$ due to NADH oxidation.

Enzyme extracts for analyses of AAO activities were prepared by homogenizing 5 to $10 \mathrm{~g}$ fresh weight spinach tissue in a prechilled mortar and pestle nestled in ice along with $0.5 \mathrm{~g}$ inert sand, 0.1 g PVP, and 20-mL ice-cold extraction buffer (100 mm potassium phosphate and $0.5 \mathrm{~mm}$ EDTA at $\mathrm{pH} 7.0$ ). Extracts were then centrifuged at $16,000 g_{n}$ for $20 \mathrm{~min}$ at $4{ }^{\circ} \mathrm{C}$. Supernatants were passed through a mini-column (Sephadex G25 PD-10) preequilibrated with the extraction buffer. AAO activity was determined in a $1-\mathrm{mL}$ assay mixture containing $25 \mathrm{~mm}$ potassium phosphate ( $\mathrm{pH} 7.5$ ), 0.5 mM EDTA, and $30 \mu \mathrm{L}$ extract. The reaction was initiated with the addition of $125 \mu \mathrm{m}$ ascorbate. The reaction was followed at $25^{\circ} \mathrm{C}$ every $30 \mathrm{~s}$ for $4 \mathrm{~min}$ by measuring the decrease in absorbance at $265 \mathrm{~nm}$ due to ascorbate oxidation.

Protein concentration of the enzyme extracts was determined spectrophotometrically at $595 \mathrm{~nm}$ using the Bio-Rad Protein Assay Dye Reagent Concentrate (Bio-Rad Laboratories, Hercules, Calif.) using the method described by Bradford (1976). Bovine gammaglobulin $\left(0.25\right.$ to $\left.1.4 \mathrm{mg} \cdot \mathrm{mL}^{-1}\right)$ was used as a standard reference.

Ascorbate LEVEls. Reduced ascorbate (AsA), oxidized ascorbate (DHA), and total ascorbate (AsA + DHA) were determined spectrophotometrically according to Law et al. (1983) as modified by Hodges et al. (1996). A 7.5 to $10 \mathrm{~g}$ fresh weight sample of spinach tissue was homogenized over ice with $0.5 \mathrm{~g}$ inert sand and $15 \mathrm{~mL}$ of ice-cold freshly prepared $5 \%(\mathrm{w} / \mathrm{v}) \mathrm{m}$-phosphoric acid with a mortar and pestle. The homogenate was centrifuged at $10,000 g_{n}$ for $15 \mathrm{~min}$ at $4{ }^{\circ} \mathrm{C}$. Total ascorbate was determined by incubating at $25^{\circ} \mathrm{C}$ for $50 \mathrm{~min}$ in a $700-\mu \mathrm{L}$ total volume containing

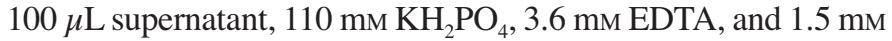
dithiothreitol (DTT) to reduce all DHA to AsA. After incubation, $100 \mu \mathrm{L}$ of $0.5 \%$ (w/v) N-ethylmaleimide (NEM) was added to remove excess DTT. AsA was treated in a similar manner except that $200 \mu \mathrm{L}$ deionized $\mathrm{H}_{2} \mathrm{O}$ was substituted for DTT and NEM. Color was developed in both series of reaction mixtures (total and reduced ascorbate) with the addition of $400 \mu \mathrm{L} 10 \%$ (w/v) TCA, $400 \mu \mathrm{L} \mathrm{44 \%} o$-phosphoric acid, $400 \mu \mathrm{L}$ of $65 \mathrm{~mm} \alpha, \alpha$-dipyridyl in $70 \%$ ethanol, and $200 \mu \mathrm{L} 110 \mathrm{~mm} \mathrm{FeCl}_{3}$. The reaction mixtures were then incubated at $40{ }^{\circ} \mathrm{C}$ for $1 \mathrm{~h}$ in a shaking water bath $(\mathrm{Ju}-$ labo Labortechnik, Seelbach, Germany) and quantified at $525 \mathrm{~nm}$. 
AsA and DHA standards were between 0 and $5 \mathrm{~mm}$ in $5 \%(\mathrm{w} / \mathrm{v})$ $m$-phosphoric acid. For each sample, DHA was estimated from the difference between total ascorbate and AsA.

Statistical ANALYSIS. All results represent at least three measurements each of three replicate samples from two harvests. Effects of harvest, cultivar, and storage were analyzed using a completely randomized design. Data were subjected to analysis of variance procedures and least significant differences were calculated using Genstat (rel. 4.21) software (Genstat 5 Committee, 1997). Unless otherwise noted, only results significantly different at $P \leq 0.05$ are discussed.

\section{Results}

LIPID PEROXIDATION. Oxidative stress, as estimated by malondialdehyde (MDA) levels, dramatically increased after day 7 in detached leaves of both spinach cultivars during $28 \mathrm{~d}$ of storage,

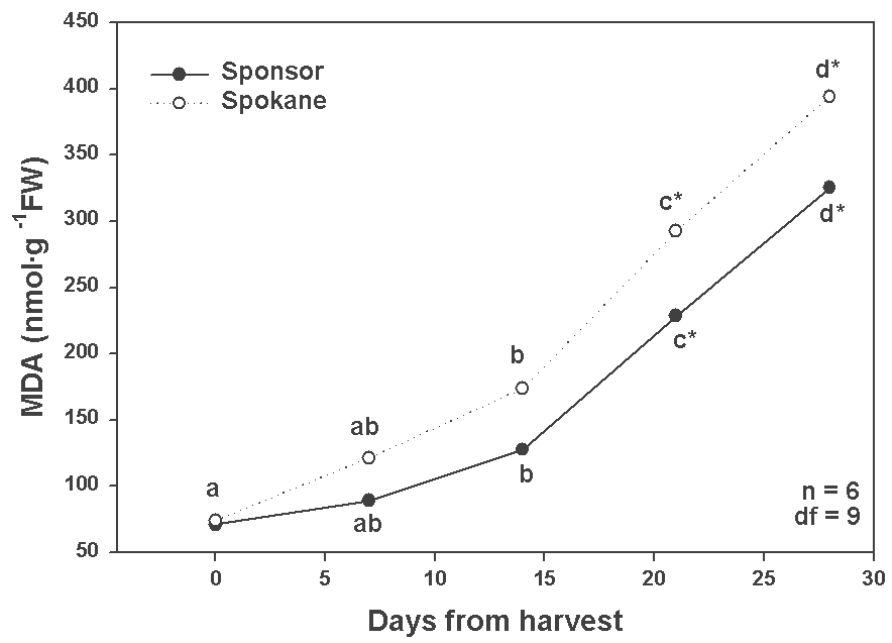

Fig. 1. Changes in MDA (nmol. $\mathrm{g}^{-1}$ fresh weight) concentrations over time in detached leaves of the spinach cultivars 'BJ 412 Sponsor' and 'Spokane F1' stored at $10{ }^{\circ} \mathrm{C}$ in the dark with $\geq 95 \%$ relative humidity. Results represent six independent replicate samples from two harvests. Letters indicate significant differences $(P \leq 0.05)$ within cultivars over time, while asterisks $\left(^{*}\right)$ represent differences between cultivars on particular storage days.

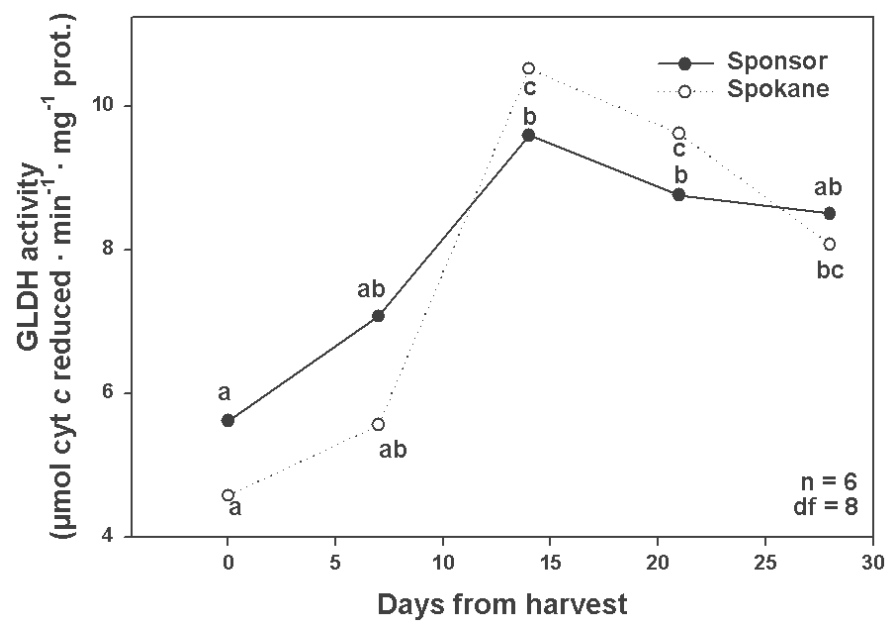

Fig. 2. Changes in GLDH activities ( $\mu \mathrm{mol}$ cytochrome c reduced/min/mg protein) over time in detached leaves of the spinach cultivars 'BJ 412 Sponsor' and 'Spokane F1' stored at $10{ }^{\circ} \mathrm{C}$ in the dark with $\geq 95 \%$ relative humidity. Results represent six independent replicate samples from two harvests. Letters indicate significant differences $(P \leq 0.05)$ within cultivars over time. There was no difference between cultivars on particular storage days. but increased more rapidly in 'Spokane' than in 'Sponsor' following day 14 (Fig. 1).

Ascorbate bIOSYNTHesis. Activities of GLDH increased on day 14 in both cultivars, after which point activities remained essentially unchanged until the end of the storage regime on day 28 (Fig. 2). No differences in GLDH activities were noted between 'Spokane' and 'Sponsor' over the duration of the 28-d storage period.

Ascorbate metabolism. Activities of ASPX, MDHAR, and DHAR declined in both 'Spokane' and 'Sponsor' during the 28-d storage period (Figs. 3-5). Although there were no differences observed in MDHAR or DHAR activities between the two cultivars (Figs. 4 and 5), ASPX activities were lower in 'Spokane' than in 'Sponsor' after day 21 (Fig. 3). Moreover, ASPX activities decreased in 'Spokane' on day 14 but not until day 21 in 'Sponsor'. However, MDHAR activity declined in 'Sponsor' on day 14 but

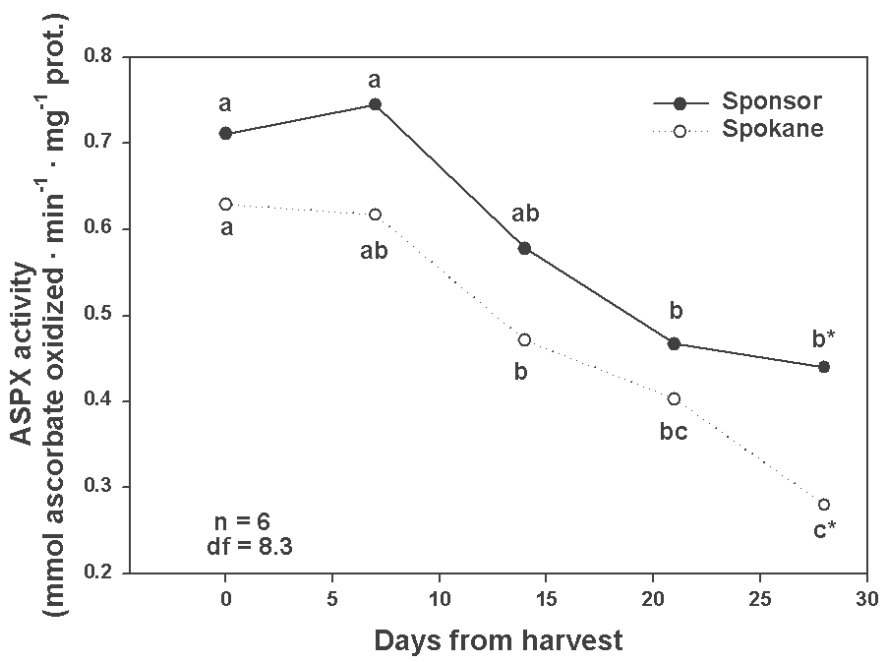

Fig. 3. Changes in ASPX activities ( $\mathrm{mmol}$ ascorbate oxidized/min/mg protein) over time in detached leaves of the spinach cultivars 'BJ 412 Sponsor' and 'Spokane F1' stored at $10^{\circ} \mathrm{C}$ in the dark with $\geq 95 \%$ relative humidity. Results represent of six independent replicate samples from two harvests. Letters indicate significant differences $(P \leq 0.05)$ within cultivars over time, while asterisks $(*)$ represent differences between cultivars on particular storage days.

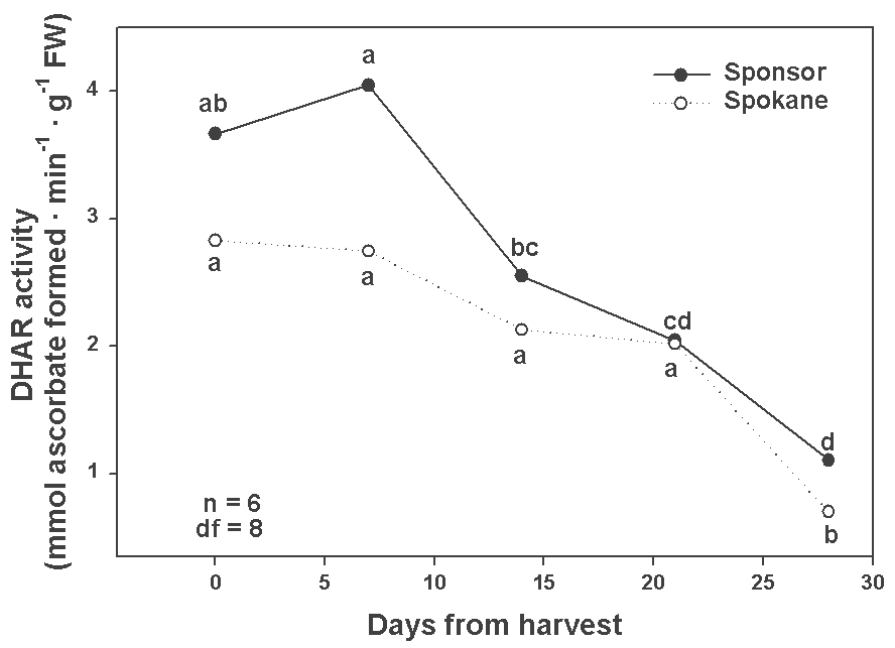

Fig. 4. Changes in DHAR activities (mmol ascorbate formed/min/g fresh weight) over time in detached leaves of the spinach cultivars 'BJ 412 Sponsor' and 'Spokane F1' stored at $10^{\circ} \mathrm{C}$ in the dark with $\geq 95 \%$ relative humidity. Results represent six independent replicate samples from two harvests. Letters indicate significant differences $(P \leq 0.05)$ within cultivars over time. There was no difference between cultivars on particular storage days. 


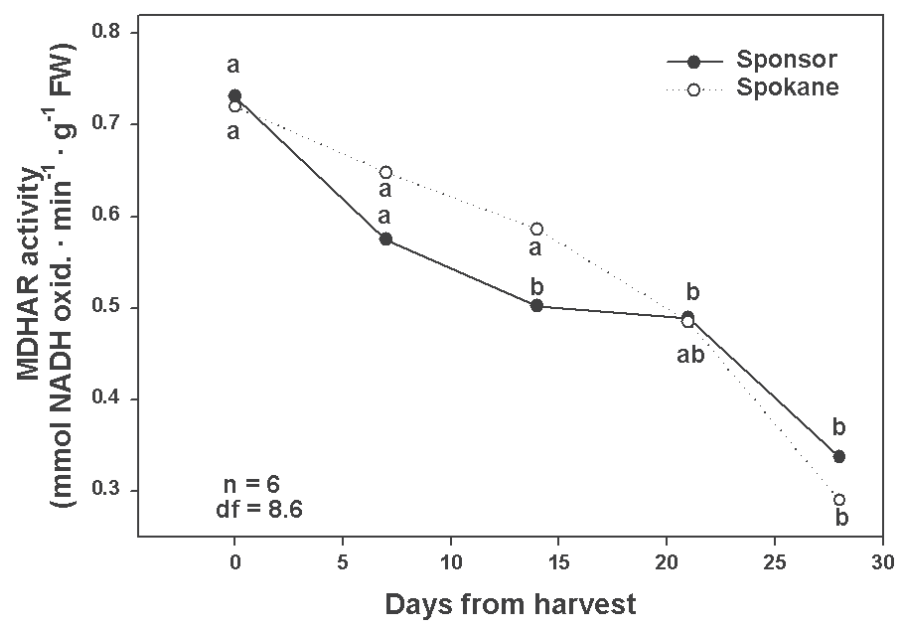

Fig. 5. Changes in MDHAR activities (mmol NADH oxidized $/ \mathrm{min} / \mathrm{g}$ fresh weight) over time in detached leaves of the spinach cultivars 'BJ 412 Sponsor' and 'Spokane F1' stored at $10{ }^{\circ} \mathrm{C}$ in the dark with $\geq 95 \%$ relative humidity. Results represent six independent replicate samples from two harvests. Letters indicate significant differences $(P \leq 0.05)$ within cultivars over time. There was no difference between cultivars on particular storage days.

not until day 28 in 'Spokane' (Fig. 5). AAO activities within the two cultivars remained unchanged over the 28-d storage period, and no differences in AAO activities were observed between 'Spokane' and 'Sponsor' during this storage term (Fig. 6).

ASCORBATE LEVELS. Total ascorbate concentrations declined in both cultivars on day 14, after which no further significant changes were noted (Fig. 7A). Early in the storage regime (days 0 and 7), ascorbate levels were lower in 'Spokane' than in 'Sponsor', but this difference disappeared after day 7. No differences in total ascorbate levels were noted between the two cultivars over the duration of the experiment.

No changes in the oxidized to reduced (DHA to AsA) ratio of ascorbate were observed for 'Sponsor' until day 28, at which point the ratio increased (Fig. 7B). For 'Spokane', however, DHA/AsA values increased on day 7 and remained at this level for the duration of the experiment. No differences in DHA/AsA values between 'Sponsor' and 'Spokane' were observed during the 28-d storage regime.

\section{Discussion}

Active oxygen species (AOS), such as superoxide $\left(\mathrm{O}_{2}^{-}\right)$and hydrogen peroxide $\left(\mathrm{H}_{2} \mathrm{O}_{2}\right)$, have been implicated in the regulation, properties, and/or dynamics of both stress-induced and natural senescence processes (Hodges, 2003). One of the major characteristics of plant senescence is increased lipid peroxidation (Kunert and Ederer, 1985; Lacan and Baccou, 1998). Levels of MDA, a secondary by-product of lipid peroxidation, provide an estimate of the degree of plant oxidative stress (Hodges et al., 1999). Similar to that reported in Hodges et al. (2001), the present study demonstrated that the detached and stored leaves of the spinach cultivar Spokane F1 exhibited a more rapid rate and higher level of MDA accumulation than did leaves of 'BJ 412 Sponsor'. In our previous study (Hodges et al., 2001), it was proposed that since 'Spokane' exhibited declining activities of ASPX and a more rapid loss in total leaf ascorbate over a 21-d storage period than in detached leaves of 'Sponsor', there existed a greater potential for lipid peroxidation in this cultivar which was manifested in an increased rate of postharvest leaf senescence. Other studies have suggested that ascorbate plays a direct role

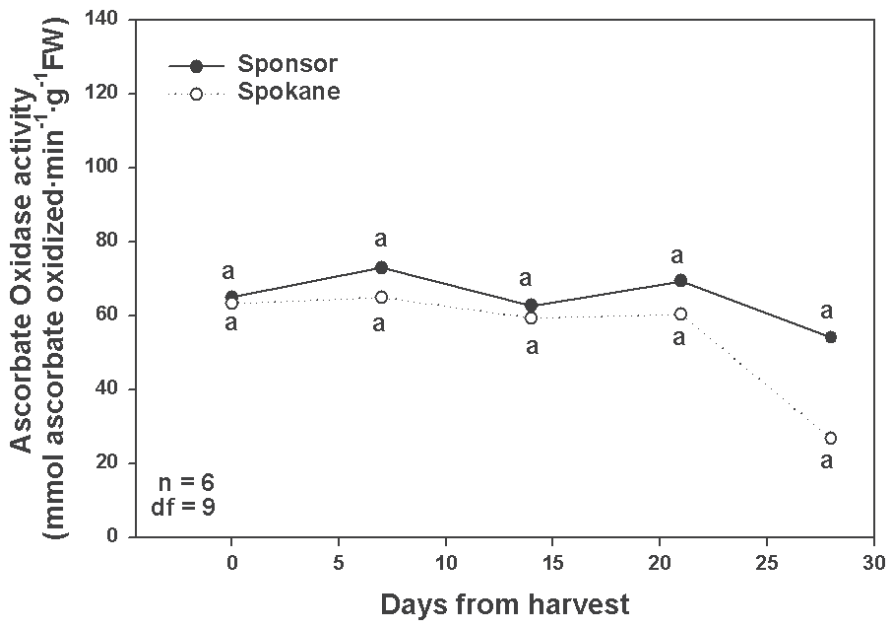

Fig. 6. Changes in AAO activities (mmol ascorbate oxidized $/ \mathrm{min} / \mathrm{g}$ fresh weight) over time in detached leaves of the spinach cultivars 'BJ 412 Sponsor' and 'Spokane F1' stored at $10^{\circ} \mathrm{C}$ in the dark with $\geq 95 \%$ relative humidity. Results represent six independent replicate samples from two harvests. Letters indicate significant differences $(P \leq 0.05)$ within cultivars over time. There was no difference between cultivars on particular storage days.

in delaying senescence, possibly through the inhibition of $\mathrm{H}_{2} \mathrm{O}_{2}$ proliferation (Borraccino et al., 1994; Hodges and Forney, 2000; Jiménez et al., 1998; Piquery et al., 2000).

L-ascorbic acid is a well-established key component of the plant antioxidant system (Noctor and Foyer, 1998). Additionally, ascorbate has been proposed to have roles in the regulation of photosynthesis, cell expansion, and trans-membrane electron transport (as cited in Pallanca and Smirnoff, 2000). The pathway of ascorbate biosynthesis in plants is different from that of animals. Although many steps remain to be thoroughly elucidated, the last step in the pathway involves the conversion of L-galactono$\gamma$-lactone to ascorbate in a step catalyzed by GLDH (Ostergaard et al., 1997; Bartoli et al., 2000).

Borraccino et al. (1994) reported that incubating oat (Avena sativa L.) leaf segments in L-galactono- $\gamma$-lactone resulted in increased levels of endogenous ascorbate and a lower rate of leaf segment senescence. In the present study, both MDA levels and GLDH activities increased on d 14 in detached leaves of both spinach cultivars during postharvest storage. Although MDA levels, and hence oxidative stress, continued to increase beyond day 14, GLDH activities remained stable thereafter. It is possible that the initial increase in GLDH activities represented a strategy to maintain the ascorbate pool against escalating oxidative stress. Even though GLDH activities increased on day 14 and maintained these levels in leaves of both cultivars until the end of the storage experiment, the decrease in ascorbate levels in both 'Sponsor' and 'Spokane' on day 14 suggests that ascorbate was being degraded at a more rapid rate than it could be synthesized. Both fruits and vegetables generally exhibit a gradual decrease in total ascorbate concentrations as postharvest storage duration increases (Lee and Kader, 2000). Although no differences in GLDH activities were noted between the two cultivars with varying senescence rates throughout the storage regime, total ascorbate levels were lower on days 0 and 7 in 'Spokane', the cultivar exhibiting a more rapid rate of senescence. It is possible that this initially lower level of ascorbate in 'Spokane' predisposed this spinach cultivar to greater oxidative stress later in storage. As postharvest activities of GLDH were similar between the two cultivars, these lower initial levels of ascorbate in 'Spokane' may have resulted from preharvest GLDH activities or, for that matter, influence from 


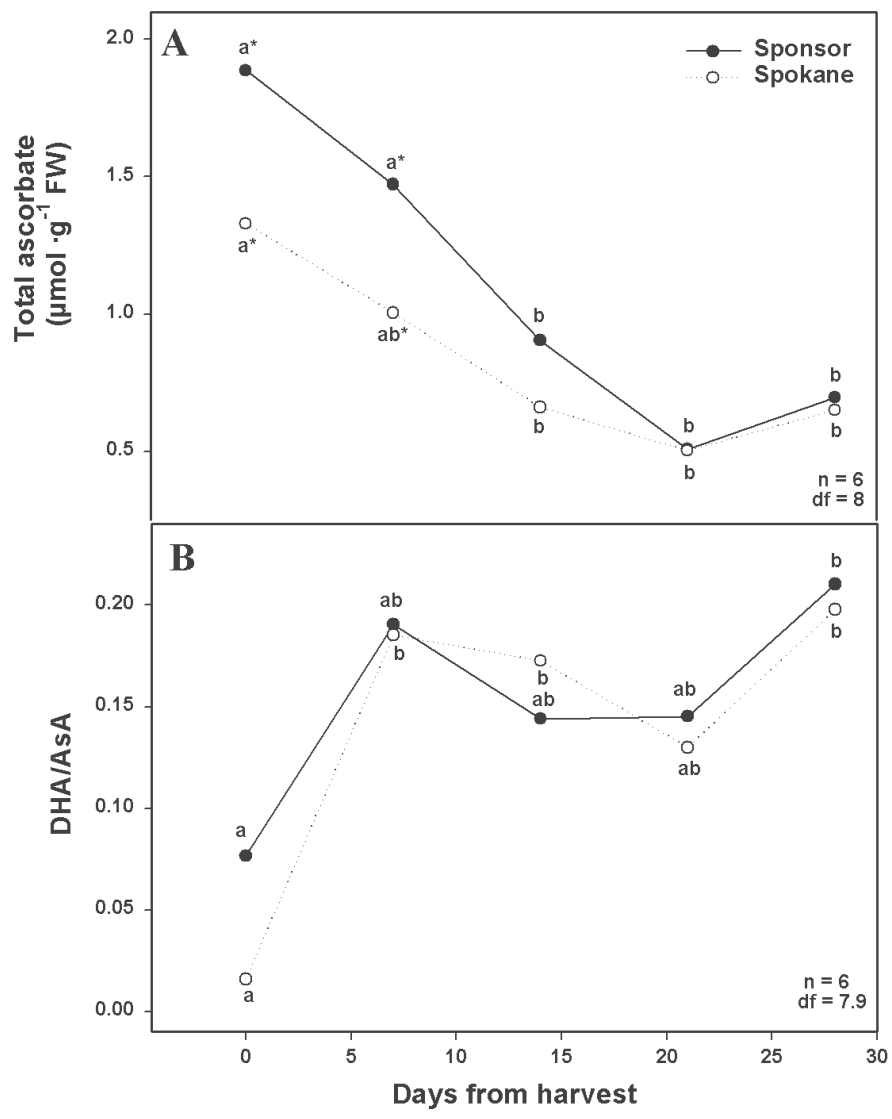

Fig. 7. Changes in A) total ascorbate concentrations ( $\mu \mathrm{mol} \cdot \mathrm{g}^{-1}$ fresh weight $)$ and $\left.\mathrm{B}\right)$ DHA/AsA over time in detached leaves of the spinach cultivars 'BJ 412 Sponsor' and 'Spokane F1' stored at $10^{\circ} \mathrm{C}$ in the dark with $\geq 95 \%$ relative humidity. Results represent six independent replicate samples from two harvests. Letters indicate significant differences $(P \leq 0.05)$ within cultivars over time, while asterisks $(*)$ represent differences between cultivars on particular storage days.

other enzymic and/or nonenzymic components of the ascorbate biosynthetic pathway.

Although ASPX activities, which oxidize ascorbate to DHA, decreased in detached leaves of the two cultivars of spinach during storage, ascorbate can also be oxidized through participation in other antioxidant functions such as direct reactions with the active oxygen species $\mathrm{O}_{2}^{-}, \bullet \mathrm{OH}$, and ${ }^{1} \mathrm{O}_{2}$ (Buettner and Jurkiewicz, 1996) and the regeneration of $\alpha$-tocopherol (Horemans et al., 2000). This, combined with reductions in the activities of the ascorbatereducing enzymes MDHAR and DHAR during storage, may have contributed to the increase in the DHA/AsA values observed for both cultivars during the 28-d storage period. Presumably, total leaf ascorbate concentrations in the spinach cultivars decreased during storage as the lactone ring of increasing amounts of relatively unstable DHA were being irreversibly hydrolyzed to form 2,3-diketogulonate, which is very unstable and degrades further to products such as xylose, oxalate, and threose (Koshiishi et al., 1998; Simpson and Ortwerth, 2000). Although in our previous study DHA to AsA values remained constant over $21 \mathrm{~d}$ of storage in 'Spokane' and even slightly decreased on day 21 in 'Sponsor' (Hodges et al., 2001), in this experiment DHA to AsA ratios were stable for $21 \mathrm{~d}$ in 'Sponsor', after which point they increased, and also significantly increased early in storage (day 7) in 'Spokane'. DHA/AsA values often increase as a response to stress and/or senescence (Gossett et al., 1994; Hodges and Forney, 2000; Walker and McKersie, 1993).

No changes were observed in AAO activities over the 28-d storage period for either cultivar, nor were any significant differences observed in activities of this enzyme between cultivars. However, AAO activities were noted to dramatically increase during senescence of both tomato (Lycopersicum esculentum L.) and bell pepper (Capsicum annuum L.) fruit (Yahia et al., 2001).

Initially lower ascorbate levels on days 0 and 7 and the more rapid decline and lower overall activities of ASPX observed in 'Spokane' likely contributed to the greater susceptibility to oxidative stress during storage exhibited by this cultivar as compared to 'Sponsor'. Although the potential to synthesize ascorbate was not different between the two cultivars throughout storage, the more rapid increase in DHA/AsA values in 'Spokane' (day 7) as compared to 'Sponsor' (day 28) may have led to higher ascorbate loss due to DHA delactonization, manifested as lower ascorbate concentrations early in storage. Lower ASPX activities in 'Spokane' late in storage would have resulted in less potential for $\mathrm{H}_{2} \mathrm{O}_{2}$ reduction than in 'Sponsor'. The lower inherent capability of 'Spokane' to use ascorbate as an antioxidant as effectively as 'Sponsor' may have resulted in comparatively faster senescence and postharvest degradation.

\section{Literature Cited}

Bartoli, C.G., M. Simontacchi, E. Montaldi and S. Puntarulo. 1996. Oxidative stress, antioxidant capacity and ethylene production during ageing of cut carnation (Dianthus caryophyllus) petals. J. Expt. Bot. 47:595-601.

Bartoli, C.G. G.M. Pastori, and C.H. Foyer. 2000. Ascorbate biosynthesis in mitochondria is linked to the electron transport chain between the complexes III and IV. Plant Physiol. 123:335-344.

Borraccino, G., L. Mastropasqua, S. De Leonardis, and S. Diperro. 1994. The role of the ascorbic acid system in delaying the senescence of oat (Avena sativa L.) leaf segments. J. Plant Physiol. 144:161-166.

Bradford, M.M. 1976. A rapid and sensitive method for the quantification of microgram quantities of protein using the principle of protein dye-binding. Anal. Biochem. 72:248-254.

Buchanan-Wollaston, V. 1997. The molecular biology of leaf senescence. J. Expt. Bot. 48:181-199.

Buettner, G.R. and B.A. Jurkiewicz. 1996. Chemistry and biochemistry of ascorbic acid, p. 91-115. In: E. Cadenas and L. Packer (eds.). Handbook of antioxidants. Marcel Dekker, New York.

De Gara, L., M.C. de Pinto, and O. Arrigoni. 1997. Ascorbate synthesis and ascorbate peroxidase activity during the early stage of wheat germination. Physiol. Plant. 100:894-900.

De Gara, L., C. Paciolla, M.C. De Tuillo, M. Motto, and O. Arrigoni. 2000. Ascorbate-dependent hydrogen peroxide detoxification and ascorbate regeneration during germination of a highly productive maize hybrid: Evidence of an improved detoxification mechanism against reactive oxygen species. Physiol. Plant. 109:7-13.

Deutsch, J.C. 1998. Oxygen-accepting antioxidants which arise during ascorbate oxidation. Anal. Biochem. 265:238-245.

Doulis, A.G., N. Debian, A.H. Kingston-Smith, and C.H. Foyer. 1997. Differential localization of antioxidants in maize. Plant Physiol. 114: 1031-1037.

Ederli, L., S. Pasqualini, P. Batini, and M. Antonielli. 1997. Photoinhibition and oxidative stress: Effects on xanthophyll cycle, scavenger enzymes and abscisic acid content in tobacco plants. J. Plant Physiol. 151:422-428.

Genstat 5 Committee. 1997. Genstat release 4.21 reference manual. Clarendon Press, Oxford, U.K.

Gossett, D., E.P. Millhollon, and M.C. Lucas. 1994. Antioxidant response to $\mathrm{NaCl}$ stress in salt-tolerant and salt-sensitive cultivars of cotton. Crop Sci. 34:706-714.

Hodges, D.M. 2003. Overview: oxidative stress and postharvest produce, p. 1-23. In: D.M. Hodges (ed.). Postharvest oxidative stress in horticultural crops. Haworth Press, Binghamton, N.Y. 
Hodges, D.M., C.J. Andrews, D.A. Johnson, and R.I. Hamilton. 1996. Antioxidant compound responses to chilling stress in differentially sensitive inbred maize lines. Physiol. Plant. 98:685-692.

Hodges, D.M., J.M. DeLong, C.F. Forney, and R.K. Prange. 1999. Improving the thiobarbituric acid-reactive-substances assay for estimating lipid peroxidation in plant tissues containing anthocyanin and other interfering compounds. Planta 207:604-611.

Hodges, D.M. and C.F. Forney. 2000. The effects of ethylene, depressed oxygen and elevated carbon dioxide on antioxidant profiles of senescing spinach leaves. J. Expt. Bot. 51:645-655.

Hodges, D.M., W.V. Wismer, and C.F. Forney. 2001. Antioxidant responses in harvested leaves of two cultivars of spinach differing in senescence rates. J. Amer. Soc. Hort. Sci. 126:611-617.

Horemans, N., C.H. Foyer, G. Potters, and H. Asard. 2000. Ascorbate function and associated transport systems in plants. Plant Physiol. Biochem. 38:531-540.

Hossain, M.A., Y. Nakano, and K. Asada. 1984. Monodehydroascorbate reductase in spinach chloroplasts and its participation in regeneration of ascorbate for scavenging hydrogen peroxide. Plant Cell Physiol. 25: 385-395.

Jiménez, A., J.A. Hernández, G. Pastori, L.A. del Rio, and F. Sevilla. 1998. Role of the ascorbate-glutathione cycle of mitochondria and peroxisomes in the senescence of pea leaves. Plant Physiol. 118:1327-1335

Kanazawa, S., S. Sano, T. Koshiba, and T. Ushimaru. 2000. Change in antioxidative enzymes in cucumber cotyledons during natural senescence: comparison with those during dark-induced senescence. Physiol. Plant. 109:211-216.

Kato, N. and M. Esaka. 2000. Expansion of transgenic tobacco protoplasts expressing pumpkin ascorbate peroxidase is more rapid than that of wild-type protoplasts. Planta 210:1018-1022.

Koshiishi, I., Y. Mamura, J. Liu, and T. Imanari. 1998. Degradation of dehydroascorbate to 2,3-diketogulonate in blood circulation. Biochim. Biophys. Acta 1425:209-214.

Kunert, K.J. and M. Ederer. 1985. Leaf ageing and lipid peroxidation: The role of the antioxidants vitamins $\mathrm{C}$ and E. Physiol. Plant. 65:85-88.

Lacan, D. and J.-C. Baccou. 1998. High levels of antioxidant enzymes correlates with delayed senescence in nonnetted muskmelon fruit. Planta 204:377-382.

Law, M.Y., S.A. Charles, and B. Halliwell. 1983. Glutathione and ascorbic acid in spinach (Spinacia olerace $\mathrm{L}$.) chloroplasts: The effect of hydrogen peroxide and of paraquat. Biochem. J. 210:899-903.

Lee, S.K. and A.A. Kader. 2000. Preharvest and postharvest factors influencing vitamin $\mathrm{C}$ content of horticultural crops. Postharvest Biol.
Technol. 20:207-220.

Nakano, A. and K. Asada. 1987. Purification of ascorbate peroxidase in spinach chloroplasts: Its inactivation in ascorbate-depleted medium and reactivation by monodehydroascorbate radical. Plant Cell. Physiol. 28: $131-140$

Noctor, G. and C.H. Foyer. 1998. Ascorbate and glutathione: Keeping active oxygen under control. Annu. Rev. Plant Physiol. Plant Mol. Biol. 49:249-279.

Ostergaard, J., G. Persiau, M.W. Davey, G. Bauw, and M. Van Montagu. 1997. Isolation of a cDNA coding for L-galactono- $\gamma$-lactone dehydrogenase, an enzyme involved in the biosynthesis of ascorbic acid in plants - Purification, chracterization, cDNA cloning, and expression in yeast. J. Biol. Chem. 272:30009-30016.

Pallanca, J.E. and N. Smirnoff. 2000. The control of ascorbic acid synthesis and turnover in pea seedlings. J. Expt. Bot. 51:669-674.

Philosoph-Hadas, S., S. Meir, and N. Aharoni. 1991. Effects of wounding on ethylene biosynthesis and senescence of detached spinach leaves. Physiol. Plant. 83:241-246.

Piquery, L., C. Davoine, C. Huault, and J.-P. Billard. 2000. Senescence of leaf sheaths of ryegrass stubble: change in enzymes activities related to $\mathrm{H}_{2} \mathrm{O}_{2}$ metabolism. Plant Growth Regul. 30:71-77

Saito, K. 1996. Formation of L-ascorbic acid and oxalic acid from Dglucose in Lemna minor. Phytochemistry. 41:145-149.

Simpson, G.L.W. and B.J. Ortwerth. 2000. The nonoxidative degradation of ascorbic acid at physiological conditions. Biochim. Biophys. Acta 1501:12-24.

Smirnoff, N. 2000. Ascorbic acid: metabolism and functions of a multifacetted molecule. Curr. Opin. Plant Biol. 3:229-235.

Trippi, V. and K.V.Thimann. 1983. The exudation of solutes during senescence of oat leaves. Physiol. Plant. 58:21-28.

Walker, M.A. and B.D. McKersie. 1993. Role of the ascorbate-glutathione antioxidant system in chilling resistance of tomato. J. Plant Physiol. 141:234-239.

Yahia,E.M., M. Contreras-Padilla, and G. Gonzalez-Aguilar. 2001. Ascorbic acid content in relation to ascorbic acid oxidase and polyamine content in tomato and bell pepper fruits during development, maturation and senescence. Lebensm. -Wiss. u.-Technol. 34:452-457.

Yamauchi, N. and A. Kusabe. 2001. Involvement of ascorbate-glutathione cycle in senescence of stored broccoli (Brassica oleracea L.). J. Jpn. Soc. Hort. Sci. 70:704-708.

Zee, J.A., L. Carmichael, D. Codère, D. Poirier, and M. Fournier. 1991. Effect of storage conditions on the stability of vitamin $C$ in various fruits and vegetables produced and consumed in Quebec. J. Food Comp. 4:77-86. 